\title{
The Leadership Orientations of the Students Receiving Sports Education in Turkey
}

\author{
Sebahattin Devecioğlu ${ }^{1}$ \\ ${ }^{1}$ Department of Sports Management, Faculty of Sports Sciences, Firat University, Elazig, Turkey \\ Correspondence: Sebahattin Devecioglu, Department of Sports Management, Faculty of Sports Sciences, Firat \\ University, 23200, Elazig, Turkey. Tel 90-53-2341-6283 E-mail: sdevecioglu@gmail.com
}

Received: March 12, 2018

Accepted: May 11, $2018 \quad$ Online Published: July 28, 2018

doi: $10.5539 /$ ies.v $11 \mathrm{n} 8 \mathrm{p} 58$

URL: https://doi.org/10.5539/ies.v11n8p58

\begin{abstract}
This research has been planned to identify the factors related to the assessment of "The Leadership Orientations" of the students receiving sports education (physical education and sports teacher, sports management, recreation, trainer education departments) in the universities in Turkey. This descriptive study has a population consisting of the students receiving sports education in the universities in Turkey and a sample of totally 1032 students (N: 1032) (who attend physical education and sports teacher, sports management, recreation, trainer education departments). The data has been collected using The Student Information Form and the Leadership Orientation Survey. According to the means of sub-scales of "Leadership Orientations by Sexes" obtained by the students receiving sports education, a significant difference has been identified between the frames of "Transformational Leadership" and "Charismatic Leadership". This difference can be explained by the fact that male students consider themselves more competent compared to the female students in these two sub-scales. Consequently, when the mean points of the sub-scales of the Leadership Orientation Survey [Self] obtained by the students receiving sports education in Turkey are compared, it has been observed that the direction and strength of relation between sex, class, department and school is "positive" and "moderate" and also those students have "people-oriented leadership" characteristics among the sub-scales of the leadership orientation frames.
\end{abstract}

Keywords: leadership, sports education, sports management

\section{Introduction}

Leadership can be defined as the combination of the skills and knowledge to gather a group of people around certain goals and motivate individuals to achieve these goals (Eren, 2010). A leader's role behaviours, strategy and tactics are influential on performance of the duties and achievement of adaptation within an organization as well as the followers' values, believes and behaviours (Helvac1, 2010).

Since leadership is a concept difficult to be defined exactly, it is considered as a complex subject by the organizational academicians (Theodore, 1981). Many definitions on leader and leadership have been made. Leadership is defined as motivating others to act in line with the intended purpose and as exercising authority to take decisions. Leadership is considered as a function of personal traits, behaviour or characteristics of a position possessed. In this scope, a leader's role is to ensure that others produce an effective performance (Mullins, 1996). To collect these definitions on a common ground, leadership is defined as the process, skill or art to affect, motivate and encourage all individuals within an organization in order to achieve the defined goals (Hellriegel \& Scolum, 1992; Black \& Porter, 2000; Robbins, 1998; Eren, 2007).

It is clear that leadership is fundamental for the effectiveness of work groups and for the organizations to which they belong (Pecino \& Santa-Bárbara, 2000).

Leadership must respond effectively to the new needs of organizations: innovation, cultural diversity, work-based knowledge, communication, and work groups. Work groups play a central role in organizations, and leadership is essential for the effectiveness of these teams (Judge \& Piccolo, 2004; O’Reilly, Caldwell, Chatman, Lapiz, \& Self, 2010).

Because of their characteristics and diversity, today's organizations represent fertile ground for the study of leadership models, More specifically, globalization, new technologies, communication, and economic and social trends challenge organizations with new leadership roles and functions (Burke \& Cooper, 2006). 
The need to face new challenges in a globalized world requires leaders to accept a complex role which involves combining continuity with innovation, based on a solid foundation of social values, ethical principles and the practice of integrating groups of professionals from different areas.

In comparison with typical traditional leadership, there have emerged new models of leadership much more dynamic and in step with reality. Thus, we see other types of leadership, for example, the transformational model which demonstrates positive correlations not only among different individual variables in the leader (ethics, emotional management, knowledge-building, etc.), but also with results at the organizational level (better performance, higher team satisfaction) (Imbroda-Ortiz, Castillo-Rodríguez, \& Chinchilla-Minguet, 2015).

The classification of leadership theories varies according to the related literature. For instance, Can (1997) has made the following classification of the leadership theories: possession of certain traits, behavioural theories, situational leadership models and the latest developments in leadership theories. Başaran (1998) has made the following classification of the leadership theories: traits theories, transactional leadership theories, contextual leadership theories and contingent leadership theories. Hodgetts (1999) and Çev, Çetin, and Mutlu (1999) have gathered the leadership theories under two titles: traits theory and situational theory. While Mullins (2005) has classified the leadership theories as qualitative/behavioural attitudes, functional attitudes, behavioural attitudes, situational attitudes, transformational leadership and inspirational leadership, Robbins, Judge, and Hasham (2012) have made another classification between theories and inspirational attitudes. Based on the classifications made in the literature, the leadership theories have been examined under four categories including Traits Approach, Behavioural Leadership Theories, Situational Leadership Theories and New Approaches in Leadership in this study (Acar, 2014).

The previous studies have shown that effective leaders sometimes don't have the same traits and some group members don't become a leader although they have more traits compared to a leader's. Also, the Traits Approach couldn't respond to the question on how to raise a good leader. Therefore, this situation has necessitated addressing other variables in order to understand the leadership process completely (Koçel, 2003).

Scholars have recognized the importance of leadership in the sport industry; early sport leadership studies emerged as early as the 1970s (Brassie, 1989).

Since then, scholars have developed and pursued numerous lines of leadership research situated in sport, investigating a myriad of leadership styles and behaviours and their relation to individual, dyadic, group, and organizational outcomes in the context of both the on-the-field athletic team and the off-the-field conventional management of the sport organization itself. Within sport leadership specifically, the sport psychology discipline has traditionally concerned itself with on-the-field team aspects of sport leadership (e.g., the coach leading the team), whereas the sport management discipline has centered more on leadership in the conventional off-the-field aspect of sport (e.g., the athletic director providing leadership to an intercollegiate athletics department). To date, however, there has been no comprehensive review of the sport management leadership literature (Peachey, Zhou, Damon, \& Burton, 2015).

\section{Method}

This research has been planned to identify the factors related to the assessment of "The Leadership Orientations" of the students receiving sports education (physical education and sports teacher, sports management, recreation, trainer education departments) in the universities in Turkey.

In line with this goal, the following questions have been tried to be responded:

- What kind of leadership behaviours do the students receiving sports education demonstrate?

- Is there a relation between the students' sexes and leadership orientations?

- Is there a relation between the students' school, department, class and graduation status and leadership orientations?

\subsection{Participants}

In this descriptive study, the population consisting of the students receiving sports education (physical education and sports teacher, sports management, recreation, trainer education departments) in the universities in Turkey.

This research aims at the students who receive sports education (physical education and sports teacher, sports management, recreation, trainer education departments) in the universities in Turkey and who satisfy the criteria to be involved in the sample. The research sample consists of 1039 students who are in their first, second, third and fourth year of university education and have bachelor's degree and who are volunteer to take part in the research online on the data collection days. 
Table 1. Distribution of the academic units that give sports education in universities in Turkey

\begin{tabular}{|c|c|c|c|}
\hline \multicolumn{3}{|c|}{ Academic Units (2015-2016) } & Number Academic Units \\
\hline \multicolumn{3}{|c|}{ Faculty of Education } & 4 \\
\hline \multicolumn{3}{|c|}{ Faculty of Health Sciences } & 3 \\
\hline \multicolumn{3}{|c|}{ School of Physical Education and Sports } & 52 \\
\hline \multicolumn{3}{|c|}{ School of Sports Sciences and Technology } & 1 \\
\hline \multicolumn{3}{|c|}{ School of Applied Sciences } & 1 \\
\hline \multicolumn{3}{|c|}{ Faculty of Sports Sciences } & 16 \\
\hline \multicolumn{3}{|c|}{ Total } & 77 \\
\hline \multirow{3}{*}{ Total } & \multirow{2}{*}{ Number of Universities that give sports education } & \multirow{2}{*}{ Number of Academic Units } & Number of Students \\
\hline & & & Daytime education Evening Education \\
\hline & 75 & 264 & 9505 \\
\hline
\end{tabular}

The number of academic units that carry on their activities in universities as of the end of 2015-2016 in Turkey (YÖK, www.osym.gov.tr).

\subsection{Design}

This is a descriptive research. Descriptive research does not fit neatly into the definition of either quantitative or qualitative research methodologies, but instead it can utilize elements of both, often within the same study. The term descriptive research refers to the type of research question, design, and data analysis that will be applied to a given topic. Descriptive statistics tell what is, while inferential statistics try to determine cause and effect (Knupfer \& McLellan, 1996).

\subsubsection{Data Collection Tools}

The personal traits of the students receiving sports education in universities in Turkey have been investigated using the Student Information Form and their leadership orientations have been examined through "Leadership Orientation Survey". The questionnaire form has been applied online in line with the call for questionnaire via the social media groups followed by the students receiving sports education.

\subsubsection{Student Information Form}

This form includes the questions related to the traits of students receiving sports education in terms of their personality (gender) and school (school, department, class, graduation).

\subsubsection{Leadership Orientations Survey}

It has been developed by Bolman and Deal (1990) to assess students' leadership characteristics.

The first section of this survey (Section I: Leadership Behaviours: The Leadership Orientation) includes the questions on leadership behaviours and its second section (Section II: Leadership Style-The Leadership Orientations Survey Instrument) involves the questions related to leadership style and third section (Section III: Overall rating) contains the questions on assessment of an individual's perceptions as a manager and leader (Bolman \& Deal, 1990; Dereli, 2003; McArdle, 2008).

In this study, the first section of the survey (Section I: Leadership Behaviours: The Leadership Orientation) regarding the leadership behaviours has been used. The section that assesses the leadership behaviours contains 32 items with a 5-point Likert scale. The Leadership Orientation (Section I) consists of four frames including People-Oriented Leadership, Structure-Oriented Leadership, Transformational Leadership and Charismatic Leadership with 32 items. Each frame has 8 items (Item 2, 6, 10, 14, 18, 22, 26 and 30 for People-Oriented Leadership; Item 1, 5, 9, 13, 17, 21, 25 and 29 for Structure-Oriented Leadership; Item 3, 7, 11, 15, 19, 23,27 and 31 for Transformational Leadership and Item 4, 8, 12, 16, 20, 24, 28 and 32 for Charismatic Leadership). This survey with a 5-point Likert scale contains 32 expressions. Each expression is scored as follows: $1=$ Never; 2 = Occasionally; 3 = Sometimes, 4 = Often; and 5 = Always. Minimum 8 points and maximum 40 points can be obtained from each frame. A high score obtained from the frames of the survey indicates that the person always displays the related behaviour while a low score means that he/she never exhibits the leadership characteristics (Dereli 2003; McArdle, 2008).

The validity and reliability of the survey in Turkey (Dereli, 2003) was studies on primary school teachers and principals in the year 2003. In Dereli's study, Cronbach alfa internal consistency coefficient was reported to be between 0.84 and 0.88 for the sub-scales of the survey. Since the Turkish version of the survey is valid and 
reliable and due to its applicability and intelligibility coefficient, it has been decided to use the survey in this study (Özkan, Akın, \& Durna, 2015).

\subsubsection{The Research Restrictions}

One of the research restrictions is the fact that this study has been performed with the students receiving sports education (physical education and sports teacher, sports management, recreation, trainer education departments) in the universities in Turkey. Another restriction is that all variables that may affect students' perceptions of leadership haven't been examined.

\subsubsection{Data Analysis and Assessment}

For the statistical assessment of the data, SPSS for Windows (Statistical Package for Social Sciences) 21.0 package program has been used in the research. The descriptive statistical techniques such as frequency, arithmetic mean, standard deviation and percent have been used for the data analysis. The significance level has been taken as $\mathrm{p}<0.05$. The suitability of the data for normal distribution has been tested by One Sample Kolmogorov Smirnov Test. Non-parametric tests have been used for advanced analyses. Of the non-parametric tests, Mann-Whitney U test has been used for two independent variables; Kruskal-Wallis test for multiple independent variables and Spearman's correlation analysis for the analysis of relations. The lowest and highest means have been obtained by male students among the participants. The lowest mean is 1 while the highest one is 4.97 . The difference between the means is $1 \leq \bar{X} \leq 4.97$.

\section{Results}

Table 2. The findings on the demographic characteristics of the students having participated in the research

\begin{tabular}{lcccc}
\hline Demographic & Sex & School & Department & Class \\
\hline $\mathrm{N}$ & 1032 & 1032 & 1032 & 1032 \\
Mean $\bar{X}$ & 1.78 & 1.57 & 2.00 & 3.30 \\
Std. Deviation & .415 & .496 & .992 & 1.389 \\
\hline Variables & & & & \\
\hline Sex & $\mathrm{f}$ & $\%$ & \\
Women & 228 & 22.1 & \\
Men & 804 & 77.9 & \\
Total & 1032 & 100.0 & \\
School & $\mathrm{f}$ & $\%$ & \\
Faculty & 447 & 43.3 & \\
High School & 585 & 56.7 & \\
Total & 1032 & 100.0 & \\
Department & $\mathrm{f}$ & $\%$ & \\
Teacher & 398 & 38.6 & \\
Management & 345 & 33.4 & \\
Trainer & 180 & 17.4 & \\
Recreation & 109 & 10.6 & \\
Total & 1032 & 100.0 & \\
Class & $\mathrm{f}$ & 13.2 & \\
$1^{\text {st }}$ Class & 136 & 20.3 & \\
$2^{\text {nd }}$ Class & 210 & 16.3 & \\
$3^{\text {rd }}$ Class & 168 & 24.1 & \\
$4^{\text {th }}$ Class & 249 & 100.0 & \\
Graduate & 269 & & \\
Total & 1032 & & & \\
\hline & & & & \\
\end{tabular}

In Table 2, examining the personal traits of the students receiving sports education in universities in Turkey, a great majority of students $(77.9 \%)$ are female. The students that have participated in the research are mostly (56.7\%) studying in School of Physical Education and Sports. Of these students, 38.6\% attend teacher department and $26.1 \%$ are graduate students. 
Table 3. The relation between the points of variables and leadership orientation survey means

\begin{tabular}{lcccccccc}
\hline \multirow{2}{*}{ Variables } & \multicolumn{9}{c}{ Sub-Scales Of Leadership Orientation Survey } \\
\cline { 2 - 9 } & \multicolumn{2}{c}{$\begin{array}{c}\text { People-Oriented } \\
\text { Leadership }\end{array}$} & \multicolumn{2}{c}{$\begin{array}{c}\text { Structure-Oriented } \\
\text { Leadership }\end{array}$} & \multicolumn{2}{c}{$\begin{array}{c}\text { Transformational } \\
\text { Leadership }\end{array}$} & \multicolumn{2}{c}{$\begin{array}{c}\text { Charismatic } \\
\text { Leadership }\end{array}$} \\
\cline { 2 - 9 } & $\mathrm{Rs}$ & $\mathrm{P}$ & $\mathrm{Rs}$ & $\mathrm{P}$ & $\mathrm{Rs}$ & $\mathrm{P}$ & $\mathrm{Rs}$ & $\mathrm{P}$ \\
\hline Sex & 0.43 & $0.00^{* *}$ & 0.39 & $0.00^{* *}$ & 0.41 & $0.00^{* *}$ & 0.38 & $0.00^{* *}$ \\
School & 0.45 & $0.00^{* *}$ & 0.38 & $0.00^{* *}$ & 0.40 & $0.00^{* *}$ & 0.41 & $0.00^{* *}$ \\
Department & 0.43 & $0.00^{* *}$ & 0.41 & $0.00^{* *}$ & 0.40 & $0.00^{* *}$ & 0.41 & $0.00^{* *}$ \\
Class & 0.43 & $0.00^{* *}$ & 0.41 & $0.00^{* *}$ & 0.41 & $0.00^{* *}$ & 0.41 & $0.00^{* *}$ \\
Mean & 0.43 & $0.00^{* *}$ & 0.39 & $0.00^{* *}$ & 0.40 & $0.00^{* *}$ & 0.40 & $0.00^{* *}$ \\
\hline
\end{tabular}

Rs: Sperman Correlation Coefficient; $* \mathrm{P}<0.05 ; * * \mathrm{P}<0.01$.

In Table 3, when the means of the sub-scales of leadership orientation survey obtained by the students receiving sports education are compared, a significant relation has been seen in terms of the direction and strength of the relation between sex, class, department and school.

Table 4. Distribution of leadership orientation survey points

\begin{tabular}{|c|c|c|}
\hline $\begin{array}{l}\text { Leadership } \\
\text { Orientations }\end{array}$ & Distribution of Leadership Orientation Survey Points & $\begin{array}{l}\text { Mean } \pm \text { S.D }(\mathrm{N}: \\
1032)\end{array}$ \\
\hline \multirow{9}{*}{$\begin{array}{l}\text { People-Oriented } \\
\text { Leadership }\end{array}$} & Q22-I'm a good listener and generally open to other people's ideas and contributions. & $4.26 \pm .944$ \\
\hline & Q 18-I'm open to others and help them consistently. & $4.14 \pm .978$ \\
\hline & Q 10-I'm sensitive to other people's needs and emotions. & $4.14 \pm .879$ \\
\hline & Q 6-I give a sense of security through open and cooperative relationships. & $4.21 \pm .986$ \\
\hline & Q 14-I encourage people to play an active role and participate in decision-taking process. & $4.12 \pm .963$ \\
\hline & Q 26-I appreciate people for their good works. & $4.29 \pm .930$ \\
\hline & Q 2-I support other people and pay attention to their problems. & $4.12 \pm .897$ \\
\hline & Q 30-I'm a leader that encourages participation. & $3.97 \pm 1.037$ \\
\hline & Sub-Scale Of People-Oriented Leadership & $4.19 \pm 0.94$ \\
\hline \multirow{8}{*}{$\begin{array}{l}\text { Structure-Oriented } \\
\text { Leadership }\end{array}$} & $\begin{array}{l}\text { Q 5-I highlight the importance of careful planning and timely completion of the planned } \\
\text { works. . }\end{array}$ & $4.13 \pm .967$ \\
\hline & Q 21-I identify clear and measurable objectives and hold people accountable for the results. & $3.63 \pm 1.004$ \\
\hline & Q 17-I have a realistic and logical approach towards problems. & $4.26 \pm .940$ \\
\hline & Q 13-I develop and implement clear and rational policies and processes. & $3.87 \pm .941$ \\
\hline & Q 1-I think clearly and logically. & $3.99 \pm .932$ \\
\hline & Q 25-I attach importance to details. & $4.00 \pm 1.110$ \\
\hline & Q 29-I believe in the necessity of educational institutions and hierarchy in them. & $3.81 \pm 1.269$ \\
\hline & Q 9-I believe that problems can be resolved by logical analysis and careful thinking. & $4.41 \pm .858$ \\
\hline \multirow{10}{*}{$\begin{array}{l}\text { Transformational } \\
\text { Leadership }\end{array}$} & Sub-Scale Of Structure-Oriented Leadership & $4.01 \pm 1.002$ \\
\hline & Q 31-I accomplish despite conflicts and oppositions. & $3.71 \pm 1.161$ \\
\hline & Q 3-I have the skill to motivate people and use resources effectively to perform the works & $3.96 \pm 1.001$ \\
\hline & Q 7-I’m successful and skilful to persuade the people having opposing views. & $3.61 \pm 1.143$ \\
\hline & Q 11-I have good ability to persuade and I'm influential. & $3.88 \pm 1.049$ \\
\hline & Q 23-I'm sensitive and skilful in terms of political attitude. & $3.56 \pm 1.173$ \\
\hline & Q 15-I foresee in-class conflicts and disputes and try to settle them firmly. & $3.37 \pm 1.151$ \\
\hline & Q 19-I'm effective to get other powerful people's support. & $3.77 \pm 1.071$ \\
\hline & $\begin{array}{l}\text { Q 27-I develop coalitions with in-school and out-of-school groups (stakeholders) to provide } \\
\text { sufficient support. }\end{array}$ & $3.79 \pm 1.222$ \\
\hline & Sub-Scale Of Transformational Leadership & $3.69 \pm 1.121$ \\
\hline \multirow{5}{*}{$\begin{array}{l}\text { Charismatic } \\
\text { Leadership }\end{array}$} & Q 20-I instil a strong and challenging sense of vision and mission. & $4.00 \pm 1.037$ \\
\hline & $\begin{array}{l}\text { Q 12-I'm a source of inspiration for other people. I develop and implement clear and rational } \\
\text { policies and processes. }\end{array}$ & $3.77 \pm 1.005$ \\
\hline & Q 24-I create new and exciting opportunities beyond the existing realities. & $3.70 \pm 1.044$ \\
\hline & Q 32-I'm a model leader with my personality for the surrounding people. & $4.03 \pm 1.022$ \\
\hline & Q 28-I instil loyalty and eagerness. & $4.01 \pm .964$ \\
\hline
\end{tabular}




$\begin{array}{lc}\text { Q 4-I motivate other people to do their best. } & 4.13 \pm .956 \\ \text { Q 8-I'm a charismatic person. } & 3.67 \pm 1.226 \\ \text { Q 16-I have a strong imagination and I'm creative. } & 4.10 \pm 1.139 \\ \text { Sub-Scale Of Charismatic Leadership } & 3.92 \pm 1.049\end{array}$

In Table 4, significant differences have been seen in the means of sub-scales of Leadership Orientation Survey obtained by the students receiving sports education.

Table 5. Distribution of leadership orientation survey points by gender

\begin{tabular}{|c|c|c|c|c|}
\hline & & \multicolumn{3}{|c|}{$\begin{array}{c}\text { Gender Ranks } \\
\text { (N 1032) }\end{array}$} \\
\hline \multicolumn{2}{|c|}{ Sub-Scales of Leadership Orientation Survey } & Women & Men & \\
\hline & & Mean Rank & Mean Rank & \\
\hline \multirow{8}{*}{ People-Oriented Leadership } & Q22 & 540.00 & 509.84 & .140 \\
\hline & Q 18 & 536.86 & 510.73 & .210 \\
\hline & Q10 & 473.82 & 528.60 & .008 \\
\hline & Q6 & 502.92 & 520.35 & .396 \\
\hline & Q14 & 520.15 & 515.47 & .823 \\
\hline & Q26 & 535.18 & 511.20 & .237 \\
\hline & Q 2 & 542.40 & 509.16 & .112 \\
\hline & Q30 & 455.25 & 533.87 & $.000 * *$ \\
\hline \multirow{8}{*}{ Structure-Oriented Leadership } & Q5 & 453.06 & 534.49 & $.000^{* *}$ \\
\hline & Q21 & 401.0 & 549.25 & $.000^{* *}$ \\
\hline & Q17 & 495.09 & 522.57 & .178 \\
\hline & Q13 & 598.61 & 493.21 & $.000 * *$ \\
\hline & Q1 & 504.61 & 519.87 & .464 \\
\hline & Q25 & 551.00 & 506.72 & $.035^{*}$ \\
\hline & Q29 & 424.66 & 542.54 & $.000 * *$ \\
\hline & Q9 & 599.77 & 492.89 & $.000^{* *}$ \\
\hline \multirow{8}{*}{ Transformational Leadership } & Q31 & 428.13 & 541.56 & $.000 * *$ \\
\hline & Q3 & 466.64 & 530.64 & $.003 *$ \\
\hline & Q7 & 463.61 & 531.50 & $.002 *$ \\
\hline & Q11 & 404.86 & 548.16 & $.000 * *$ \\
\hline & Q23 & 550.09 & 506.97 & $.047^{*}$ \\
\hline & Q15 & 427.93 & 541.62 & $.000 * *$ \\
\hline & Q19 & 517.44 & 516.23 & .955 \\
\hline & Q27 & 536.55 & 510.81 & .229 \\
\hline \multirow{8}{*}{ Charismatic Leadership } & Q20 & 518.41 & 515.96 & .908 \\
\hline & Q12 & 494.47 & 522.75 & .187 \\
\hline & Q24 & 542.70 & 509.07 & .116 \\
\hline & Q32 & 577.61 & 499.17 & $.000^{* *}$ \\
\hline & Q28 & 471.47 & 529.27 & .009 \\
\hline & Q4 & 530.74 & 512.46 & .382 \\
\hline & Q8 & 405.11 & 548.09 & $.000^{* *}$ \\
\hline & Q16 & 470.27 & 529.61 & $.004 *$ \\
\hline
\end{tabular}

$* \mathrm{P}<0.05 ; * * \mathrm{P}<0.0$.

In Table 5, differences have been seen between the male and female participants in terms of sub-scales of Leadership Orientation Survey. 
Table 6. Mann-Whitney test results of the sub-scales of leadership orientation survey points by departments

\begin{tabular}{cccccc}
\hline & \multicolumn{3}{c}{ Gender Ranks } \\
\cline { 2 - 6 } Sub-Scales Of Leadership Orientation \\
\cline { 2 - 6 } Survey & \multicolumn{3}{c}{ Women } & \multicolumn{3}{c}{ Men } \\
& \multicolumn{2}{c}{ N 228 } & \multicolumn{3}{c}{ N 804 } \\
\cline { 2 - 6 } & Mean Rank & Sum of Ranks & Mean Rank & Sum of Ranks \\
\hline People-Oriented Leadership & 486,95 & 111025,00 & 524,88 & 422003,00 &, 088 \\
Structure-Oriented Leadership & 506,11 & 111025,00 & 519,45 & 417634,50 &, 549 \\
Transformational Leadership & 474,59 & 108206,00 & 528,39 & 424822,00 &, 016 \\
Charismatic Leadership & 478,93 & 109195,00 & 527,16 & 423833,00 &, 031 \\
\hline
\end{tabular}

In Table 6, there is a significant difference between Transformational Leadership and Charismatic Leadership. This difference can be explained by the fact that male students consider themselves more competent compared to the female students in these two sub-scales.

Table 7. Distribution of the leadership orientation survey points by departments

\begin{tabular}{|c|c|c|c|c|c|c|}
\hline \multirow{3}{*}{\multicolumn{2}{|c|}{$\begin{array}{l}\text { Sub-Scales of Leadership } \\
\text { Orientation Survey }\end{array}$}} & \multicolumn{5}{|c|}{ Department Ranks } \\
\hline & & \multirow{2}{*}{$\begin{array}{c}\text { Teacher } \\
\text { N } 398 \\
\text { Mean Rank }\end{array}$} & \multirow{2}{*}{$\begin{array}{l}\text { Management } \\
\quad \text { N } 345 \\
\text { Mean Rank }\end{array}$} & \multirow{2}{*}{$\begin{array}{c}\text { Trainer } \\
\text { N } 180 \\
\text { Mean Rank } \\
\end{array}$} & \multirow{2}{*}{$\begin{array}{l}\text { Recreation } \\
\text { N } 109 \\
\text { Mean Rank }\end{array}$} & \multirow[b]{2}{*}{$\mathrm{P}$} \\
\hline & & & & & & \\
\hline \multirow{9}{*}{$\begin{array}{l}\text { People-Oriented } \\
\text { Leadership }\end{array}$} & & & & & & \\
\hline & Q22 & 533.69 & 541.89 & 443.56 & 493.83 & $.000^{* *}$ \\
\hline & Q18 & 415.43 & 564.99 & 530.44 & 709.03 & $.000 * *$ \\
\hline & Q10 & 404.82 & 542.64 & 614.85 & 679.14 & .000 \\
\hline & Q 6 & 532.50 & 443.78 & 520.58 & 681.50 & .000 \\
\hline & Q14 & 524.52 & 460.30 & 551.78 & 606.84 & .000 \\
\hline & Q26 & 449.83 & 495.97 & 616.20 & 660.25 & .000 \\
\hline & Q 2 & 497.66 & 458.92 & 526.70 & 750.70 & .000 \\
\hline & Q30 & 551.24 & 430.94 & 533.52 & 632.38 & .000 \\
\hline \multirow{8}{*}{$\begin{array}{l}\text { Structure-Oriented } \\
\text { Leadership }\end{array}$} & Q5 & 506.28 & 486.66 & 548.39 & 595.61 & $.001 *$ \\
\hline & Q21 & 490.39 & 532.44 & 501.63 & 585.93 & $.010^{*}$ \\
\hline & Q17 & 460.03 & 493.86 & 541.18 & 753.61 & .000 \\
\hline & Q13 & 508.29 & 540.63 & 442.57 & 592.20 & .000 \\
\hline & Q1 & 581.85 & 414.25 & 517.21 & 600.33 & .000 \\
\hline & Q25 & 487.31 & 435.25 & 563.12 & 803.24 & .000 \\
\hline & Q29 & 467.55 & 476.64 & 635.64 & 624.67 & .000 \\
\hline & Q9 & 473.71 & 475.79 & 562.54 & 725.57 & .000 \\
\hline \multirow{8}{*}{$\begin{array}{l}\text { Transformational } \\
\text { Leadership }\end{array}$} & Q31 & 565.89 & 446.83 & 437.13 & 687.77 & .000 \\
\hline & Q3 & 496.73 & 496.46 & 494.15 & 689.04 & .000 \\
\hline & Q7 & 540.52 & 514.76 & 514.89 & 436.97 & $.011^{*}$ \\
\hline & Q11 & 550.58 & 561.41 & 467.08 & 331.51 & .000 \\
\hline & Q23 & 464.33 & 514.17 & 574.12 & 619.22 & .000 \\
\hline & Q15 & 578.50 & 451.80 & 481.49 & 552.72 & .000 \\
\hline & Q19 & 496.42 & 467.21 & 553.68 & 684.41 & .000 \\
\hline & Q27 & 495.02 & 456.89 & 554.33 & 721.14 & .000 \\
\hline \multirow{8}{*}{$\begin{array}{l}\text { Charismatic } \\
\text { Leadership }\end{array}$} & Q20 & 521.17 & 485.47 & 535.58 & 566.16 & $.037 *$ \\
\hline & Q12 & 508.28 & 475.89 & 540.47 & 635.49 & .000 \\
\hline & Q24 & 476.85 & 464.33 & 604.22 & 681.53 & .000 \\
\hline & Q32 & 533.11 & 494.20 & 473.24 & 597.88 & $.001 *$ \\
\hline & Q28 & 550.69 & 350.88 & 672.69 & 657.95 & .000 \\
\hline & Q4 & 558.16 & 410.92 & 510.84 & 707.89 & .000 \\
\hline & Q8 & 452.92 & 482.32 & 624.37 & 678.71 & .000 \\
\hline & Q16 & 457.35 & 516.80 & 502.16 & 755.20 & .000 \\
\hline
\end{tabular}

$* \mathrm{P}<0.05 ; * * \mathrm{P}<0.01$.

In Table 7, there are significant differences between the points of sub-scales of Leadership Orientation Survey 
obtained by the students receiving sports education in terms of their departments.

Table 8 . Kruskal-Wallis test results of leadership orientation survey points by departments

\begin{tabular}{cccc}
\hline Sub-Scales of Leadership Orientation Survey & Department & N & Mean Rank \\
\hline & Teacher & 398 & 485.62 \\
People-Oriented Leadership & Management & 345 & 451.16 \\
& Trainer & 180 & 563.34 \\
& Recreation & 109 & 758.69 \\
& Teacher & 398 & 486.72 \\
Structure-Oriented Leadership & Management & 345 & 460.69 \\
& Trainer & 180 & 529.01 \\
& Recreation & 109 & 781.20 \\
Transformational Leadership & Teacher & 398 & 526.22 \\
& Management & 345 & 476.60 \\
& Trainer & 180 & 513.95 \\
Charismatic Leadership & Recreation & 109 & 611.51 \\
& Teacher & 398 & 496.30 \\
& Management & 345 & 441.41 \\
\end{tabular}

In Table 8 , there is a significant difference $(\chi 2 \mathrm{kw}=60.27 ; \mathrm{p}<0.01)$ between the general means of the sub-scales of leadership orientation survey and the departments.

\section{Discussion}

When the means of the sub-scales of leadership orientation survey obtained by students receiving sports education are compared, a significant relation has been found in terms of the direction and strength of the relations between sex, class, department and school in the research. This relation is in "positive direction" and has "moderate strength". The strongest sub-scale among the mentioned ones is "people-oriented leadership". There is a positive relation which is also the strongest one between the sub-scale of people-oriented leadership and departments (Table 3).

In the research, significant differences have been seen between the means of sub-scales of Leadership Orientation Survey obtained by the students receiving sports education. Accordingly, it has been observed that the traits of "People-Oriented Leadership Frame" are the leadership behaviours exhibited "the most" by a point of $4.19 \pm 0.94$ while the traits of "Transformational Leadership Frame" are the leadership behaviours exhibited "the least" by a point of 3.69 \pm 1.121 . In the sub-scale of "People-Oriented Leadership", the item "I appreciate people for their good

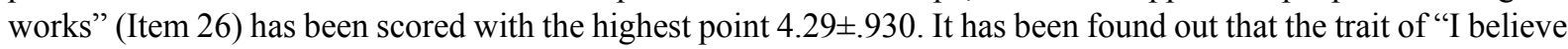
that problems can be resolved by logical analysis and careful thinking" (4.41..858) is the most important leadership trait possessed by the students receiving sports education while the trait of "I foresee in-class conflicts and disputes and try to settle them firmly" (3.37 1.151$)$ is the least important leadership trait (Table 4).

The fact that the behaviours of "People-Oriented Leadership" are the leadership characteristics exhibited the most by the students receiving sports education in Turkey can be a significant indicator of fitness of the university education for the intended purpose. Various supporting trainings and activities need to be provided for improving the students' attitudes in order to support the behaviours of "Transformational Leadership" which constitute the lowest point of the students receiving sports education and to remedy the deficiencies seen in the items of the sub-scales in the study.

The differences have been identified between the leadership orientation sub-scales of the male and female participants by the variable of sex in the research. Accordingly, it has been observed that the item of "I'm a leader that encourages participation" under the sub-scale of "People-Oriented Leadership" is a leadership behaviour displayed by "male" participants while the item of "I believe that problems can be resolved by logical analysis and careful thinking" under the sub-scale of "Structure-Oriented Leadership" is a leadership behaviour exhibited by "female" participants. Moreover, it has been seen that the item of "I accomplish despite conflicts and oppositions" under the sub-scale of "Transformational Leadership" is exhibited by "male" participants while the item of "I'm a model leader with my personality for the surrounding people" under the sub-scale of "Charismatic Leadership" is 
displayed by "female" participants (Table 5).

Among the students receiving sports education in Turkey, Charismatic Leadership is an approach that is mostly associated with people's works, positions and self-expression and it is more developed among male students. However, the fact that female participants have had the highest point in the item of "I'm a model leader with my personality for the surrounding people" under the sub-scale of "Charismatic Leadership" needs to be addressed separately. The fact that females are more consistent and more loyal to their promises compared to males supports this conclusion. On the other side, sports are more common among males and male sportsmen are generally successful, which is again a criterion for charismatic leadership.

When the environment and other factors are examined in the framework of the responses given by females under the sub-scale of "Transformational Leadership", it has been seen that females are less competent and decisive in terms of persuasion and problem-solving compared to males. The fact that males have had the highest point in the item of "I accomplish despite conflicts and oppositions" under the sub-scale of "Transformational Leadership" and females hesitate in such situations shouldn't be ignored. Women have limited skills to overcome problems and act according to the course of problems compared to men, which also supports this conclusion (Table 6).

According to the variable of departments, it has been observed in the research that the item of "I'm open to others and help them consistently" under the sub-scale of "People-Oriented Leadership" is a leadership behaviour displayed by the participants from the department of "Recreation". Also, it has been observed that the items of "I highlight the importance of careful planning and timely completion of the planned works" and "I identify clear and measurable objectives and hold people accountable for the results" under the sub-scale of "Structure-Oriented Leadership" are the leadership behaviours exhibited by the participants from the department of "Recreation". The item of "I'm successful and skilful to persuade the people having opposing views" under the sub-scale of "Transformational Leadership" has been found out to be a leadership behaviour displayed by the participants from "physical education teacher" department while the items of "I'm a model leader with my personality for the surrounding people" and "I instil a strong and challenging sense of vision and mission" under the sub-scale of "Charismatic Leadership" are exhibited by the participants from the department of "Recreation" (Table 7).

The fact that the behavioural traits of the students from the recreation department differ from those of the students attending other sports education departments in Turkey results from the fitness of the student selection criteria of these departments for the leadership training and from the leadership course practices included in the curriculum of the recreation departments.

There is a relation between the sub-scale of people-oriented leadership and departments $(\chi 2 \mathrm{kw}=98.69 ; \mathrm{p}<0.00)$ while a relation is available between the sub-scale of structure-oriented leadership and departments $(\chi 2 \mathrm{kw}=103.175 ; \mathrm{p}<0.00)$. Also, there is a relation between the sub-scale of transformational leadership and departments $(\chi 2 \mathrm{kw}=17.82 ; \mathrm{p}<0.00)$ while a relation is available between the sub-scale of charismatic leadership and departments $(\chi 2 \mathrm{kw}=84.19 ; \mathrm{p}<0.00)$. Moreover, there is a relation between "Recreation" department and other departments according to the sub-scale of "People-Oriented Leadership". By the sub-scale of "Structure-Oriented Leadership", a relation is available between "Recreation" department and other departments. There is a relation between "Recreation" department and "Trainer" departments and between "Physical Education Teacher" and "Sports Management" according to the sub-scale of "Transformational Leadership". By the sub-scale of "Charismatic Leadership", a relation is available between "Recreation" department and "Trainer" departments and between "Physical Education Teacher" and "Sports Management" (Table 8).

\section{Conclusion}

In conclusion, the fact that the curriculums of the sports education departments include leadership training supports the affinities between the departments in Turkey. The professional groups of Physical Education and Sports Teacher, Trainer Education, Sports Management and Recreation Leadership have courses with similar content for leadership training, which provides the students attending different departments with the opportunity to have common traits.

The fact that sports has human and social characteristics in any field and the students who have received sports education and will be a leader in many areas within society after graduation are endowed with the traits of "people-oriented leadership" and also the fact that they display these behaviours will contribute to the human and social development highly in terms of sports education and practices in Turkey.

Following identification of the leadership orientations of the students receiving sports education in advance according to their sexes and departments and consideration of the professional acquisitions of Physical Education and Sports Teacher, Trainer Education, Sports Management and Recreation Leadership departments, the 
leadership formation trainings included in the course content of each department should be given in accordance with their intended purpose and these students' deficiencies and insufficiencies specific to their leadership orientations should be eliminated by applied trainings.

\section{References}

Acar, V. (2014). The Leadership Orientations of Professional Tour Guides: Example of Professional Tour Guides Registered to Aydin Chamber of Tour Guides. Adnan Menderes University, Institute of Social Sciences, Department of Tourism Management, Aydın.

Başaran, İ. E. (1998). Human Relations in Management, Managerial Attitude. Aydan WEB Tesisleri: Ankara.

Black, J. S., \& Porter, L. W. (2000). Management: Meeting New Challenges. Prentice Hall, New Jersey.

Bolman, L. G., \& Deal, T. E. (1990). Leadership orientations (self). Brookline, MA: Leadership Frameworks.

Brassie, P. S. (1989). A student buyer's guide to sport management programs. Journal of Physical Education, Recreation \& Dance, 60, 25-29. https://doi.org/10.1080/07303084.1989.10609806

Burke, R. J., \& Cooper, C. (2006). Leading in turbulent times. Oxford: Blackwell.

Can, H. (1997). Organization and Management (4th ed.). Siyasal Kitabevi: Ankara.

Dereli, M. (2003). Leadership Behaviours of Primary School Principals. Department of Educational Sciences, Institute of Educational Sciences, Middle East Technical University, Post-graduate Thesis, Ankara: Organizational Behaviour and Management Psychology.

Eren, E. (2010). Organizational Behavior and Psychology. Beta Basım, İstanbul.

Hellriegel, D., \& Slocum, J. W. (1992). Management. Addison Wesley Publishing Company, New York.

Helvac1 A. (2010). The Levels of Exhibition of Ethical Leadership Behaviours by Primary School Administrators. Journal of World of Turks, 2(1), 391-402.

Hodgetts, R.M. (1999) Management Theory, Process and Practice (2nd ed., Translated into Turkish by C. Çetin and E. C. Mutlu). Beta Basım Yayım Dağıtım: İstanbul.

Imbroda-Ortiz, J., Castillo-Rodríguez, A., \& Chinchilla-Minguet, J. L. (2015). Sports Management, Leadership in the Organization. Journal of Physical Education and Sports Management, 2(2), 56-65

Judge, T. A., \& Piccolo R. F. (2004). Transformational and Transactional Leadership: A Meta-Analytic Test of Their Relative Validity. Journal of Applied Psychology, 89(5), 755-768. https://doi.org/10.1037/0021-9010.89.5.755

Knupfer, N. N., \& McLellan, H. (1996). Groupware: A Tool for Interpersonal Computing. In D. H. Jonassen (Ed.), Handbook of Research for Educational Communications and Technology: A Project of the Association for Educational Communications and Technology.

Koçel, T., (2003). Business Management (9th ed.). Beta Basım, İstanbul.

McArdle, M. K. (2008). Leadership orientations of community college presidents and the administrators who report to them: A frame analysis (A Dissertation for the degree of Doctor of Education, University of Central Florida, Orlando, Florida).

Mullıns, L. J. (1996), Management and Organizational Behaviour (6th ed., p. 651). Prentice Hall.

Mullins, L. J. (2005). Management and Organisational Behaviour (7th ed., p. 285). Pearson Education Limited: Edinburgh.

O'Reilly, C., Caldwell, D., Chatman, J., Lapiz, M., \& Self, W. (2010). How leadership matters: The effects of leaders alignment on strategy implementation. The Leadership Quartely, 21(1), 104-113. https://doi.org/10.1016/j.leaqua.2009.10.008

Özkan, N. Ö., Akın, S., Durna, Z. (2015). Nursing Students' Leadership Tendencies and Motivation Levels. Nursery Training and Research Magazine, 12(1), 51-61.

Peachey, J. W., Zhou, Y., Damon, Z. J., \& Burton, L. J. (2015). Forty Years of Leadership Research in Sport Management: A Review, Synthesis, and Conceptual Framework. Journal of Sport Management, 29, 570-587. https://doi.org/10.1123/jsm.2014-0126

Pecino, C. B., \& Santa-Bárbara, E. S. (2000). Análisis de la fiabilidad del lead (descripción de la efectividad y adaptabilidad del líder). Anales de Psicología, 16(2), 167-175. 
Robbins, S. (1998). Organisational Behaviour: Concepts, Controversies and Applications (8th ed.). New Jersey: Prentice Hall.

Robbins, S. T., Judge, T. A., \& Hasham, E. S. (2012). Organizational Behaviour (Arab World Edition, pp. 260-268). Pearson Education Limited: UK.

Theodore, H. (1981). Dimensions of Organizational Behaviour (2nd ed.). Macmillan Publishing Co., USA.

\section{Copyrights}

Copyright for this article is retained by the author(s), with first publication rights granted to the journal.

This is an open-access article distributed under the terms and conditions of the Creative Commons Attribution license (http://creativecommons.org/licenses/by/4.0/). 